THUFULI: Jurnal Pendidikan Islam Anak Usia Dini

Volume 2 Nomor 2 Tahun 2020

e-ISSN: $2685-161 \mathrm{X}$

\title{
PERKENALAN DENGAN ALIRAN FILSAFAT PENDIDIDKAN
}

\author{
Rosichin Mansur \\ Universitas Islam Malang \\ e-mail: rosichin.mansur@unisma.ac.id
}

Diterima: 23 November 2020|Direvisi: 26 November 2020|Disetujui: 27 November 2020 (C)2020 Pendidikan Guru Raudhatul Atfhal Fakultas Agama Islam Universitas Islam Malang

\begin{abstract}
The schools of educational philosophy believe in their views for development and change. The flow of philosophy makes the world of education more advanced and quality. The views of progressivism, perennialism, essentialism, constructionism and constructivism are projected in educators, students, curriculum, principles of education and learning. Early Childhood Islamic Education (PIAUD) is one of the media for actualizing the views of educational philosophical schools that are relevant to local culture. so that many schools of philosophy can be adopted.
\end{abstract}

Kata Kunci: perkenalan, aliran filsafat pendidikan

\section{A. Pendahuluan}

Filsafat Pendidikan bukan suatu barang baru di dunia pendidikan, karena filsafat pendidikan menjadi fondasi dan rujukan dalam melahirkan pemikiran, serta perkembangan dunia pendidikan. Aliran filsafat pendidkan yang menjadi pijakan terkadang tidak semuanya dirujuk, karena hanya aliran tertentu yang relevan dengan budaya dan lingkungan pendidikan yang akan dianut. Kiranya perlu perkenalan dengan isme-isme atau aliran-aliran filsafat pendidikan yang beraneka ragam, maka kita dapat mengenal lebih dekat aliranaliran filsafat pendidikan. Hal tersebut memudahkan kita untuk dapat memahami dan memilih mana yang dijadikan titik tolak pijakan dalam pelaksanaan dan pengembangan pendidikan.

Aliran filsafat pendidikan anak usia dini sangatlah banyak, salah satunya adalah Ki Hajar Dewantara dari Indonesia. Buku-buku Ki Hajar Dewantara yang asli adalah berbahasa belanda dan melayu, dan telah banyak diterjemahkan oleh pakar-pakar pendidikan agar dapat dijadikan panutan dalam menetapkan filsafat pendidikan. Negara lain juga memiliki ahli dibidang pendidikan anak

This work is licensed under Creative Commons Attribution Non Commercial 4.0 International License Available online on: http://riset.unisma.ac.id/index.php/fai/index 
usia dini, yakni Montessori dari Italia, Montessori adalah seorang dokter yang mendedikasikan dirinya pada pendidikan anak usia dini. Sekolah yang didirikan oleh Montessori adalah casa de bambini. (Montessori: 2013). Salah satu filsafat dalam bidang psikologi anak adalah Peaget. Dalam Buku "The Peaget Prier Thinking Learning Teaching" yang ditulis oleh Labinowics (1980) kita dapat memahami, bagaimana kondisi psikologi anak yang berpengaruh pada perilaku sehari-hari. Pakar Kecerdasan jamak yang sering menjadi rujukan pendidikan masa kini dicetuskan oleh Gardner. Buku Gardner yang berjudul The Frames of Mind (1983) menjelaskan tentang enam kecerdasan jamak yang dimiliki manusia. Gardner meneliti hal tersebut, karena menentang keras tes psikologi yang awalnya bertujuan untuk membantu kesulitan belajar siswa, menjadi tolak ukur kecerdasan seseorang dengan label "pintar atau bodoh". banyak sekali aliran-aliran filsafat anak usia dini yang dapat kita anut, hanya tinggal memahami dan memilih mana yang cocok untuk pendidikan kita.

\section{B. Metode}

Dalam kajian filsafat pendidikan ini metode yang digunakan, metode induktif dan dedukif. Metode induktif dimaksudkan metode dengan cara kerja yang berangkat dari hal-hal yang bersifat partikular atau khusus yang kemudian ditarik menuju kesimpulan yang bersifat general atau umum. Sebaliknya metode deduktif dimaksudkan metode dengan cara kerja yang berangkat dari hal yang bersifat general atau umum kemudian ditarik pada hal-hal yang bersifat partikular atau khusus.

\section{Hasil dan Pembahasan}

Filsafat pendidikan kontemporer seperti progresivisme, esensialisme, pereneliasme, rekontruksionisme, dan konstruktivisme memiliki pandanganpandangannya sendiri dalam dunia pendidikan. Pandangan-pandangan aliranaliran tersebut berorientasi pada perubahan dan pengembangan pendidikan yang lebih maju, dan berkualitas serta menjunjung nilai-nilai luhur. Kemunculan aliran filsafat pendidikan seringkali dipicu oleh kondisi kebudayaan atau kehidupan yang sedang berlangsung, di samping kemunculannya sebagai reaksi atau protes aliran yang satu terhadap aliran lain yang tidak mendukung terhadap perubahan-perubahan demi kemajuan dunia pendidikan, baik mengenai masalah sekolah, pendidik, peserta didik, dan proses belajar. Kendatipun berbeda dalam pandangannya di antara aliran filsafat pendidikan tersebut tetapi isme-isme tetap saling menghargai dan menghormati pandanganya tentang pendidikan yang diyakini kebenarannya. 
Progresivisme, aliran filsafat pendidikan yang lahir sebagai reaksi atas pendidikan tradisional yang membosankan dan pembelajaran yang pasif. Aliran ini menghendaki peserta didik aktif belajar untuk mengembangkan potensipotensinya, karena pendidikan pada dasarnya selalu dalam pengembangan, pengembangan individu, masyarakat dan kebudayaan (Uyoh, 2007:145). Sedangkan tujuan pendidikan diartikan sebagai pembangunan kembali pengalaman yang berjalan secara kontinyu yang bersifat progres (Djumransjah, 2006:177). Belajar aktif menjadi tuntutan anak atau peserta didik agar terus maju, dan menambah pengetahuan serta pengalamannya.

Progresivisme berpandangan bahwa pendidikan berpusat pada peserta didik. Sehingga pendidikan harus bersentuhan secara langsung minat peserta didik, minat individu. Peserta didik memiliki kebebasan untuk kreatif, inovatif dan banyak berbuat dalam proses belajar, tetapi pendidik masih diperlukan dalam memberi arahan dan bimbingan. Pendidik sebagai pembimbing peserta didik dalam pemecahan masalah, dan penolong dalam memilih dan menentukan masalah yang berarti. Sehingga pendidik harus mempunyai kesabaran, pengetahuan dan pengalaman yang lebih dibanding peserta didiknya. Adapun kurikulum dalam pendidikan progresivisme fleksibel, luas dan terbuka. Untuk mata pelajaran aliran ini menghendaki mata pelajaran yang tidak terpisah melainkan terintegrasi (Djumransjah, 2006:181). Pengalaman bagi progresivisme menjadi ciri dinamika hidup, dan hidup itu sendiri suatu perjuangan dan tindakan. Pengalaman pun menjadi kunci dan piranti dalam memahami realita yang ada. Aliran ini memandang bahwa pendidikan harus selalu mengalami kemajuan, mengalami progres yang baik. Rosseau mengatakan bahwa pendidikan harus dapat menjauhkan anak dari keburukan, dan membawa anak ke segala yang baik yang telah diberikan Tuhan (Uyoh, 2007:145).

Pandangan John Dewey, Jean Jaques Rousseau dan Sigmund Frued mendasari pendidikan progresevisme (Knight, 2007:146). Sumbangsih Dewey sebagai filosof pragmatis memberikan landasan-landasan filosofis pendidikan. Freud menekankan kebebasan lebih dalam ekpresi diri dan lingkungan yang terbuka. Sedangkan Rosseau menentang orang dewasa ikut campur tangan dalam menentukan tujuan belajar. Para tokoh tersebut memberikan andil besar dalam menginisiasi tumbuhkembang progresivisme yang memiliki pengaruh besar tehadap dunia pendidikan di Amerika. Prinsip-prinsip pendidikan progresivisme yaitu:

1) pendidikan itu bukan persiapan hidup tapi hidup itu sendiri,

2) peserta didik yang menentukan proses belajar dan peserta didik tidak pasif, 
3) peserta didik belajar memecahkan masalah melalui tahapan, dan bermanfaat bagi kehidupannya.

4) pendidik membimbing, mengarahkan dan memandu belajar peserta didik,

5) sekolah mengajarkan kerja sama, persaudaraan dan kasih sayang,

6) pembelajaran secara demokratis.

Berdasarkan prinsip-prinsip di atas kiranya dapat dipahami bahwa progresivisme menghendaki peserta didik belajar aktif, aktif dalam memecahkan masalah, dan memiliki kebebasan dalam belajar tapi pendidik masih diperlukan dalam memberi bimbingan belajar.

Perenialisme, aliran filsafat pendidikan yang mengedapan nilai-nilai keabadian atau nilai yang sifatnya abadi. Aliran ini lahir sebagai reaksi progresivisme yang mendepankan pendidikan terpusat pada peserta didik dan penyesuaian hidup. Aliran ini berpandangan bahwa pendidikan menjadi media yang memiliki peran penting dalam mengembalikan kehidupan manusia sekarang yang kacau ke kebudayaan masa lalu yang ideal dan telah teruji oleh waktu. Aliran ini dipengaruhi pemikiran Plato, Aristoteles dan Thomas Aquinas. (Djumransjah, 2006:187).

Aliran ini berpandangan tugas utama pendidikan yaitu mempersiapkan kematangan akal peserta didik dengan memberkan pengetahuan kepadanya. Sekolah menjadi tempat utama pendidikan, dan tugas pendidik memberikan pendidikan dan pengajaran kepada peserta didik untuk mengembangkan kemampuannya, dan keberhasilan peserta didik bergantung pada pendidik. Tujuan pendidikan yaitu mewujudkan peserta didik hidup bahagia. Untuk mewujudkan tujuan pendidikan itu kurikulum yang berpusat pada mata pelajaran jangan menekankan pada kepentingan jangka pendek melainkan memusatkan pada pertumbuhan intelektual peserta didik dan pemahaman kebenaran-kebenaran abadi dan hubungannya dalam kehidupan masyarakat.

Prinsip-prinsip pendidikan perenialisme yaitu:

1) Meskipun manusia berbeda lingkungan hakikatnya sama, manusia adalah hewan rasional,

2) Setiap orang mendapat pendidikan yang sama, karena watak dasar manusia tidak berubah,

3) Pendidikan terletak pada keseriusan aktivitas-aktivitasnya, bukan pada peserta didik,

4) Mempelajari karya-karya besar masa lampau yang merupakan gudang pengetahuan dan kebijaksanaan yang telah teruji waktu dan relevan dengan masa kini, dan

5) Pendidikan merupakan persiapan untuk hidup bukan peniruan hidup. 
Prinsip-prinsip tersebut di atas mencerminkan bahwa perenialisme menekankan setiap peserta didik mendapatkan pendidikan yang sama, dan pendidikan terletak pada keseriusan dalam beraktivitas serta pendidikan sebagai persiapan untuk hidup.

Esensialisme, aliran yang muncul sekitar tahun 1930-an sebagai kritik terhadap progesivisme yang merusak standar intelektual dan moral. Aliran ini merujuk pada nili-nilai luhur dan nilai-nilai kebudayaan yang ada sejak awal peradaban manusia. Esensialisme berpandangan bahwa perubabahan suatu kenyataan yang ada dalam kehidupan masyarakat. Sifat aliran ini fleksibel, terbuka, dan toleran serta tidak memiliki keterkaitan dengan doktrin trtentu. Idealisme dan realisme adalah filsafat yang melandasi pandangan esensialisme (Knight, 2007:99,176), dan salah satu pelopor esensialisme adalah Wiliam C. Bagley (Uyoh, 2007:158).

Esensialisme memandang bahwa untuk anak dapat berguna di masyarakat, anak harus mendapatkan pendidikan yang logis, disiplin, dan kerja keras. Pendidikan bertujuan mewariskan budaya dan sejarah yang telah teruji oleh waktu, serta mempersiapkan manusia untuk hidup yang terancang dalam kurikulum. Kurikulum pendidikan esensialisme ini berpusat pada mata pelajaran yang diperlukan dalam hidup dan disusun oleh pendidik. Sekolah merupakan sarana yang melestarikan dan mewariskan budaya melalui hikmat dan pengalaman. Pendidik merupakan orang yang menguasai pengetahuan, dan memiliki pengaruh besar di kelas pada peserta didik, dan pendidik yang memiliki inisiatif dalam pembelajaran. Prinsip-prinsip pendidikan esensialisme yaitu:

1) tugas sekolah adalah mengajarkan pengetahuan dasariah,

2) belajar merupakan suatu usaha keras dan menuntut kedisiplinan,

3) inisiatif pendidikan ada pada pendidik,

4) metode-metode tradisional harus dipertahanakan,

5) meningkatkan kesejahteraan umum sebagai tujuan akhir pendidikan.

Prinsip-prinsip di atas dapat menjadi cerminan esensilisme bahwa menghendaki belajar bukan aktifitas yang sembarangan melainkan usaha keras dan disiplin, dan pendidik yang menginisiasi dalam pendidikan.

\section{Rekostruksionisme}

Rekonstruksionisme, aliran filsafat pendidikan yang lahir sebagai reaksi terhadap keadaan yang tidak menentu dan kesimpasiuran. Aliran ini ingin melakukan perubahan dan membangun tatanan dunia sosial baru yang lebih baik. Rekonstruksionisme muncul skitar tahun 1930 dipelopori George S Count dan Harold Rugg yang ingin membangun sosial baru yang pantas dan adil. 
Power menyebut rekonstruksionimse ini dengan istilah neoprogresivisme (Uyoh, 2007:167,171).

Aliran ini berpandangan bahwa sekolah harus menyusun kembali tatanan masyarakat baru dari masyarakat lama yang dalam kesimpangsiuran. Sekolah sebagai agen utama dalam rekonstruksi tatanan sosial dan sumber inovasi sosial. Untuk mewujudkan tujuan tersebut harus melakukan konsesnsus dan bekerjasama antar bangsa supaya dapat mengkonstruk tatanan sosial baru di lingkungannya. Tujuan pendidikan adalah menumbuhkan kesadaran peserta didik baik dalam masalah sosial, ekonomi dan politik. Tujuan teringgi pendidikan yaitu terciptanya masyarakat baru yang saling bergantung. (Uyoh, 2007:169).

Kuruklum dalam pendidikan rekonstruksionisme terletak pada mata pelajaran. Kurikulum berisikan mengenai sosial, ekonomi, politik dan masalahmasalah yang ada dan dihadapi dalam kehidupan. Peran pendidik memberikan kesadaran peserta didik, dan membantunya dalam memecahkan masalah. Pendidik harus memberikan motivasi peserta didik agar dapat menemukan jalan alternatif dalam memecahkan masalah.

Prinsip-prinsip pendidikan rekonstruksionisme yaitu,

1) Perubahan secara mendasar pada tata masyarakat agar peradaban dunia tidak mengalami kehancuran

2) Menciptakan atau membangun tatanan sosial yang mendunia.

3) Sekolah menjadi agen utama dalam menyusun kembali tatanan sosial yang baru.

4) Sekolah harus berpartisipasi aktif mengajarkan perubahan sosial.

5) Pembelajaran berjalan secara demokratis.

Prinsip-prinsip tersebut di atas menunjukan bahwa rekonstruksionisme menghendaki perubahan yang mendasar dalam tatanan masyarakat dan membangun tatanan sosial yang mendunia. Sekolah merupakan agen perubahan dan menyusun kembali tatanan sosial yang batu.

\section{Kostruktivisme}

Konstruktivisme, aliran filsafat yang menekankan anak untuk aktif membangun pengetahuannya sendiri yang dipengaruhi pengetahuan dan pengalaman yang telah dipunyainya. Suparno (2012:18) mengungkapkan bahwa konstruktivisme adalah salah satu filsafat pengetahuan yang menekankan pengetahuan itu bentukan sendiri. Pengetahuan seseorang tidak 
dapat ditransfer kepada orang lain, anaklah yang aktif belajar. Meskipun aliran ini berada dalam filsafat pengetahuan tetapi tidak dapat dipungkiri aliran ini telah memberikan banyak kontribusi dan andil besar terhadap dunia pendidikan melalui pandangan-pandangannya dalam bidang pendidikan.

Aliran ini memandang belajar merupakan proses aktif peserta didik membangun teks, dialog, pengalaman dan yang lain Belajar berati membentuk makna, makna yang diciptakan peserta didik berdasar apa yang dilihat, didengar, dirasakan, dan dialami serta bangunan itu dipengaruhi oleh pengetahuan yang telah dimiliki (Knight, 2007:61). Belajar adalah suatu aktifitas pengembangan pemikiran hingga lahir pengertian baru. Peserta didik lah yang aktif belajar, yang membangun atau membentuk pengetahuannya, dan bertanggung jawab atas hasil belajarnya. Pengetahuan dan pengalaman yang telah dimiliki peserta didik ikut mempengaruhi dalam mengkonstruksi pengetahuan barunya. Pendidik hanya membantu mengaktifkan dan pengembangan pemikirannya. Pendidik merupkan mitra peserta didik dalam pembelajaran, sehingga pendidik pun harus memiliki pengetahuan yang luas dan mendalam, serta pemikiran yang fleksibel untuk dapat menghargai pemikiran peserta didik.

Strategi pembelajaran harus disesuaikan dengan kebutuhan peserta didik. Pendidik dapat mengembangkan strategi sendiri karena hakikatnya strategi bukan suatu yang sudah jadi. Sedangkan untuk kurikulum dipandang sebagai program aktifitas mengonstruksi pengetahuan dan ketrerampilan. Kurikulum bukan kumpulan bahan yang telah ditentukan tetapi permasalahan yang harus dipecahkan peserta didik (Suparno, 2012:76). Prinsip-prinsip pendidikan konstruktivisme yaitu:

1) Pengetahuan dibangun oleh peserta didik sendiri

2) Pengetahuan tidak dapat dipindahkan dari pendidik ke peserta didik, peserta didik sendiri yang aktif menalar

3) Peserta didik yang aktif membangun secara kontinu hingga adanya perubahan konsep menuju konsep yang ilmiah.

4) Pendidik membantu media agar pserta didik dalam proses konstruksi berjalan baik.

Berdasarkan prinsip-prinsip di atas dapat dimengerti bahwa peserta didik yang aktif membangun pengetahuan sendiri karena pengetahuan tidak dapat dipindahkan dari orang yang satu ke orang lain. Pendidik hanyalah membantu sarananya dalam proses pembetukan pengetahuan berjalan baik. 
Beberapa aliran filsafat pendidikan kiranya telah berkenalan dan memasuki di lingkungan pendidikan anak usia dini (0-6 tahun) melalui pandangan-pandangannya yang terproyeksikan dalam prinsip pendidikan anak usia dini. Seperti pandangan tentang pendidikan berpusat pada peserta didik, dan pendidikan bersifat demokratis. Dalam Indonesian Journal Islamic Early Childhod Education, Sumiyati (2016:70) mengungkapkan sepuluh prinsip pembelajaran anak usia dini yaitu:

1) belajar melalui bermain

2) pembelajaran berorientasi pada perkembangan anak

3) pembelajaran berorientasi pada kebutuhan anak

4) pembelajaran berpusat pada anak

5) anak sebagai pembelajar aktif

6) pembelajaran berorientasi pada pengembangan karakter

7) pembelajaran berorientasi pada pengembangan kecakapan hidup

8) lingkungan pembelajaran kondusif

9) pembelajaran demokratis

10) pembelajaran menggunakan bebagai sarana dan sumber belajar.

Melihat prinsip pembelajaran anak usia dini di atas dapat dipahami adanya titik-titik kesamaan dengan pandangan aliran filsafat pendidikan. Seperti prinsip ke 4 pembelajaran berpusat pada anak, prinsip ke 5 anak pembelajar aktif, kedua prinsip tersebut memiliki titik yang sama dengan pandangan progresivisme yang menekankan belajar aktif dan belajar berpusat pada peserta didik. Demikian pula dengan konstruktivisme menekankan peserta didik yang belajar aktif. Prinsip 9 pembeljaran demokratis, hal ini pun memiliki titik kesamaan dengan konstruksionisme yang berpandangan pendidikan bersifat demokratis.

Merujuk pada titik-titik kesamaan di antara pandangan aliran filsafat pendidikan dengan prinsip pendidikan anak usia dini, kiranya dapat dimengerti bahwa aliran filsafat pendidikan bukan saja berkenalan tetapi lebih dari itu telah menyatu dalam jiwa pendidikan anak usia dini yang terproyeksikan dalam prinsip pendidikan anak usia dini. Oleh karena itu pendidik pada pendidikan anak usia dini (PAUD) dan atau pendidikan Islam anak usia dini (PIAUD) harus memahami pandangan aliran-aliran filsafat pendidikan dan didukung dengan memahami budaya setempat, dan dikemas bahasa sederhana dan atau bahasa seusianya maka pendidik akan dapat lebih luwes dan demokratis dalam mengaktualisasikan prinsip pendidikan untuk kemajuan dan perkembangan pendidikan anak usia dini. 
Calon pendidik program pendidikan PIAUD/PAUD selayaknyalah mendapatkan matapelajaran filsafat pendidikan. Sehingga calon pendidik telah memiliki pengetahuan yang luas dan mendalam tentang filsafat pendidikan sebagai modal dasar dalam aktualisasi pandangan aliran filsafat pendidikan yang memiliki relevansi di lembaga pendidikan anak usia dini. Calon pendidik pun harus memahami budaya dan etika sosial di sekitarnya sehingga mempermudah dalam melakukan perubahan dan mengkonstruksi pendidikan anak usia dini dengan irama yang diinginkan.

\section{SIMPULAN}

Aliran-aliran filsafat pendidikan progrsivisme, perenialisme, esensialime, konsuksionisme dan konstruktivisme dengan pandanganpandangannya meyakini mampu melakukan perubahan dan mengantarkan dunia pendidikan ke pintu gerbang kemajuan.

Pandangan aliran filsafat pendidikan memiliki titik-titik kesamaan dengan pendidikan anak usia dini yang terproyeksikan dalam prinsip pendidikan anak usia dini seperti pendidikan berpusat pada peserta didik dan pendidikan bersifat demokratis. Titik-titik kesamaan pandangan di atas sebagai tanda perkenalan.

\section{Daftar Rujukan}

Arifi, H.M. (2000). Filsafat pendidikan Islam. Jakarta: Bumi Aksara

Daradjat, Zakiah dkk. (2008). Ilmu Pendidikan Islam. Jakarta: Bumi Aksara Djumransjah, M. (2006) Filsafat Pendidikan. Malang: Bayu Publishing Gardner, Howard. (1983). The Frames of Mind. New York: Basic Book. Hurlok, Elizabeth B. (2015). Perkembangan Anak Jilid 2. Jakarta: Erlangga Jalaludin dan Abdullah Idi. (2007). Filsafat Pendidikn. Yogyakarta: Ar Ruzz Knight, George. (2007). Filsafat Pendidikan. Penerjemah Mahmud Arif. Yogyakarka: Gama Media

Kurniawan, Heru at all. (2016). Indonesian Journal of Islamic Early Childhood

Educaation. Volume 1, Number 1, Desember 20216. ISSN 2541-2418

Labinowics, Ed. (1980). The Peaget Primer Thinking Learning Teaching. America: Addison-Wesley Publishing Company.

Montesori, Maria. Tanpa Tahun. Metode Montesori. Terjemah Gutex, Gerald Lee. 2013. Yogyakarta: Pustaka Pelajar.

Ramayulis dan Samsul Nizar. (2009). Ffilsafat Pendidikan Islam. Jakarta: Kalam Mulia 
Sadulloh, Uyoh. (2007). Pengantar Filsafat Pendidikan. Bandung: Alfabeta Suhartono, Suparlan. (2007). Filsafat Pendidikan. Jogjakarta: Ar-Ruzz Media Suparno, Paul. (2012). Filsafat Konstruktivisme dalam Pendidikan. Yogyakarta: Kanisius 